\title{
Status and distribution of Red Panda (Ailurus fulgens fulgens) in Simsime community forest of Papung VDC of Taplejung district, Nepal
}

\author{
B. Lama ${ }^{1}$
}

\begin{abstract}
Red Panda (Ailurus fulgens fulgens), globally an endangered species of Himalaya, were studied in Simsime community forest of Papung Village Development Committee (VDC) in Taplejung district.. It was carried out to assess status, habitat characteristics and threats to Red Panda. Three transects were laid out along the contours and their total length was $2200 \mathrm{~m}$. The altitude of these transects varied from $2800-3400 \mathrm{~m}$. While moving along the transect line, the signs such as pellets, footprints and nests of Red Panda were searched and the GPS points were recorded in those places where the signs were observed. The habitat was assessed simultaneously to describe its characteristics in this community forest. Square plots of $10 \mathrm{~m}{ }^{*} 10 \mathrm{~m}, 4 \mathrm{~m}{ }^{*} 4 \mathrm{~m}$ and $1 \mathrm{~m}^{*} 1 \mathrm{~m}$ were laid out to assess trees, shrubs and herbs, respectively along contour lines at an altitudinal interval of $200 \mathrm{~m}$ between $2800 \mathrm{~m}$ and $3400 \mathrm{~m}$ and the plots were spaced at a distance of $100 \mathrm{~m}$. Diameter at breast height (DBH) of major tree species (Juniperus spp., Pinus spp., Acer spp. and Rhododendron spp) was measured in the plots. The signs were found in Simsime community forest at an altitude of $3026 \mathrm{~m}$, $3125 \mathrm{~m}$ and $3127 \mathrm{~m}$. Overall sign encounter rate for this community forest was 1.36/ km. Acer spp. had the highest Importance Value Index (IVI) and Arundinaria maling was the major bamboo species with highest relative frequency (RF). Based on direct field observation, major threats to Red Panda were found to be grazing and bamboo cutting in which majority of the respondents agreed.
\end{abstract}

Key words: Assessment, encounter rate, habitat characteristics, Red Panda, status, signs, transect line

$\mathrm{R}$ ed Panda is a vegetarian member of the order carnivore mammal native to the eastern Himalayas and south-western China. It was enlisted globally as an endangered on the IUCN Red List of Threatened Species in 2015 (Ling $\mathrm{Xu}$ and Jing Guan, 2018). It is distributed throughout Himalayan Mountains of Nepal, India, Bhutan, Myanmar and China between 2200 and $4800 \mathrm{~m}$ altitude with an exceptional case in tropical forest of Meghalaya State in India. It is found in the temperate forests of Himalayas with bamboo understory (Yonzon, 2000). It was estimated to be more in the eastern part particularly along the border of Myanmar to Yunnan (Roberts and Gittleman, 1984). Many populations recorded with low densities in small fragmented patches of forests in China and Nepal have a wider elevation range in Red Panda distribution (2000-3800 m) compared to other countries (Thapa et al., 2018). In Nepal, it is recorded at least in seven protected areas (PAs) i.e. Kanchenjunga Conservation Area (KCA), Makalu Barun National Park and Buffer Zone (MBNP BZ), Sagarmatha National Park and Buffer Zone (SNP BZ), Langtang National Park and Buffer Zone (LNP BZ), Annapurna Conservation Area (ACA), Dhorpatan Hunting Reserve (DHR) and Rara National Park (RNP) (DNPWC, 1995; Yonzon et al., 1997).

These animals are recorded in those places with temperature ranging from 10 to $25^{\circ} \mathrm{C}$ and having pattern of average annual rainfall of $3500 \mathrm{~mm}$. Habitat is characterized by presence

1 Forest Research and Training Center, Ministry of Forests and Environment, Nepal, Email : bimalalama386@gmail.com 
of mixed deciduous and coniferous forest (Chakraborty, 1999). It subsists primarily on a diet of bamboo and other vegetation (Johnson et al., 1988; Choudhary, 2001; Panthi et al., 2012). Tree species such as Acer spp., Betula utilis and Quercus semicarpifolia, shrub species of Elaegnus parviflora, Jasminum humile and small sized bamboo, Drepanostachyum spp. and the herbs like Polygonatum cirrhifolium, Fragaria nubicola and Galium asperifolium were the most preferred substrate used for defecation (Bhatta et al., 2014). According to Yonzon and Hunter 1989 , about $86 \%$ of its resting sites are on trees mostly on Abies spectabilis in summer and Juniper (Juniperus spp.), Birch (Betula spp.), Rhododendron and Maple (Acer spp.) trees in winter.

The exact population of Red Panda is not known; however, the global population is estimated to be in between 9,200 - 11,000 individuals (Choudhary, 2001; Wei et al., 1999). In Nepal, a total of 314 individuals were estimated (Yonzon et al., 1997) and Nepal is home to approximately $1.9 \%$ of the total global population of the Red Panda on the basis of habitat suitability index. Out of the total potential Red Panda habitat, 38\% lies inside PAs whereas remaining 62\% lies in community managed and national forest in the country, where their population and conservation status is not known in most of the areas (DNPWC, 2010).

Red Panda has unique morphological and behavioral features that have evolved to fulfill a niche as bamboo feeders. The average length of Red Panda is $100 \mathrm{~cm}$; its body is about $60 \mathrm{~cm}$ and tail is about $40 \mathrm{~cm}$ long. The weight of adult Red Panda in wild is about $4 \mathrm{~kg}$ while in captivity they weigh 4 to $5 \mathrm{~kg}$ (Yonzon, 1989). The tails are marked with about 12 alternating red and buff rings and are not prehensile. Red Panda has round head, short rostrum, large, erect and pointed ears. The body consists of long, coarse and guard hairs and the undercoat is soft, dense and woolly. In eastern specimen, the body is darker. Its face colour is predominantly white with reddishbrown 'tear mark' extending from their eyes to the corner of their mouths (Bradford, 2016). Its fur on the upper side of the body is reddish-brown while it is glossy black ventrally. It has black legs and sole of its feet are covered with dense white hair. Front legs are angled inward, leading to its waddling walk. The feet are plantigrade. No sexual dimorphism is there in colour or size between males and females (Morris, 1965; Roberts and Gittleman, 1984; Vaughan, 1972)

Red Panda which resembles a raccoon in both size and appearance (Pradhan et al., 2001 a ; Roberts, 2001; Wei et al., 1999; Glaston, 1994) is of taxonomic importance because it is monotypic sub-family, meaning that its sub-family-Ailuridae contains only one genus Ailurus and one species (Chakraborty, 1999; Yonzon, 1989). However, there are two sub-species in Red Panda Ailurus fulgens fulgens and Ailurus fulgens styani, which split around three million years ago when torrential river flow cut the eastern Himalaya forming the Brahamaputra Gorge (Chakraborty, 1999; Wei et al., 1999).

Despite being categorized as a protected species by National Parks and Wildlife Conservation Act (1973), intensified anthropogenic activities such as livestock grazing, illegal trade, poaching, habitat loss and degradation are inducing threats for their long-term survival. According to the action plan developed by the Department of National Parks and Wildlife Conservation under the Ministry of Forests and Environment, Red Panda is usually poached for their furs and meat. Seventy-four cases of trafficking of Red Panda hides were reported in Nepal during the nine-year period from 2008 to 2016. However, the market, where Panda hides are in demand, remains unknown. Also, lack of awareness, unsustainable developmental activities, bamboo die-off, climate change and transfer of diseases from livestock and dogs are some other threats to the survival of Red Panda (Himalayan News Service, 2019)

In spite of being important species, the information on Red Panda is scarce in Nepal. There is an urgent need to explore the status of Red Panda in Nepal to enable its monitoring and conducting conservation efforts. Similarly, habitat fragmentation, forest fire, lack of water in summer, heavy collection of forest products, poaching, rotational grazing and predation by dogs, natural dying of ringal bamboo species, drought and landslides are the major threats to Red Panda. Climate change has also influenced Red Panda population. The government has developed Red Panda Conservation Action Plan (20192023) aiming the protection and management 
of Red Panda population in Nepal through a holistic approach of conservation which includes research, monitoring, awareness building, habitat improvement and threat management. So, its effective implementation requires a sound and systematic database on Red Panda status and the genetic resources it carries since it is a unique species with a taxonomic uniqueness and has been a species of interest to biologists. The status on Red Panda in protected areas has been studied while very few studies have been done outside it. Papung Village Development Committee (VDC) is one of the adjoining VDCs of Kanchenjunga Conservation Area with the possibility of presence of Red Panda but no previous study was carried out there. Thus, the finding of this study explored the current population status and distribution, habitat characteristics and threats which will be useful for the conservation and management of Red Panda.

\section{Materials and methods}

\section{Study area}

In 2011, the study was carried out in Simsime community forest (CF) located at ward numbers 3 and 4 of Papung VDC in Taplejung district (Fig. 1). This site was confirmed as potential habitat for Red Panda according to the information of Kanchenjunga Landscape Concern Group staffs, Community forest user group members, herders and local villagers. Three community forests namely Simsime CF, Bataase Damali CF and Ghyashi Pemba Phedichowk CF are located in Papung VDC. The area of Simsime community forest is 59.81 ha. The major tree species found in the study area are Juniperus spp., Pinus spp., Acer spp. and Rhododendron spp. whereas the major shrub species is Rubus ellipticus and the major bamboo species is Arundinaria maling. The total number of households in Simsime CF of Papung VDC is 65.

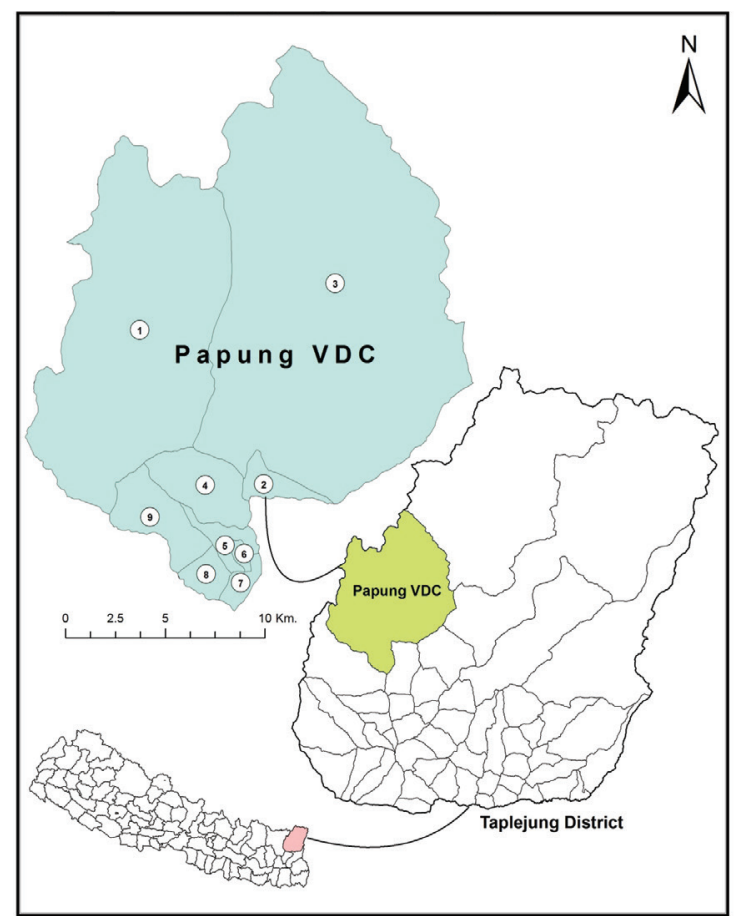

Fig. 1: Map showing the study area

\section{Data collection}

For primary data collection, the interviewed key informants were staffs of Kanchenjunga Landscape Concern Group, Community forest user group members, herders and local villagers. Based on their information, Simsime CF was selected for the study to know the population status (presence or absence) of Red Panda, its habitat characteristics, threats and the potential habitats. Three transects were laid out in an altitudinal range of $2800-3400 \mathrm{~m}$ and total length of these transects was $2200 \mathrm{~m}$. While moving along the transect line, the signs such as pellets, footprints and nests of Red Panda were searched and the GPS points were recorded in those places where the signs were observed. The Red Panda's pellets were easily identified by their shape. They are spindle in shape, rounded and thicker in the middle and pointed at both ends while the colour is normally green and grayish white when dry.

To assess the habitat characteristics of Red Panda, vegetation assessment was carried out through systematic sampling based on the altitude (Karki 1999; Mahato 2003; Shrestha 1988). Square plots of $10 \mathrm{~m}^{\star} 10 \mathrm{~m}, 4 \mathrm{~m}^{\star} 4 \mathrm{~m}$ and $1 \mathrm{~m}^{\star} 1 \mathrm{~m}$ were laid out to assess trees, shrubs and herbs Gysel and Lyon, 1980; Poudel, 2009), respectively along the contour lines at an altitudinal interval of $200 \mathrm{~m}$ 
between $2800 \mathrm{~m}$ and $3400 \mathrm{~m}$ and the plots were spaced at a distance of $100 \mathrm{~m}$. Diameter at breast height $(\mathrm{DBH})$ of major species was measured in the plots. Threats signs were assessed during field visits and also through key informants' interview with project staffs, and herders.

\section{Household survey}

Out of 65 households (HHs) in Simsime CF of Papung VDC, 24 households were surveyed to assess the perception of local villagers on the status and threats to Red Panda population.

\section{Secondary data collection}

Secondary data were collected from Department of National Parks and Wildlife Conservation (DNPWC), Institute of Forestry library, WWF Nepal staffs, published and unpublished thesis, books, research papers and journals.

\section{Data analysis}

\section{Abundance indices}

The signs of Red Panda were plotted on the base map using ArcGIS 3.2 software to show their status and distribution in the study area.

\section{Vegetation analysis}

For analysis of vegetation, SPSS and Microsoft Excel were used. The following derivations (Shrestha and Ghimire, 1996 Poudel, K. 2009) were calculated to assess habitat characteristics.

\section{a) Density and Relative density (RD)}

$\begin{array}{ll}\text { a. Density of } & \begin{array}{l}\text { Total no. of individuals of } \\ \text { species } A\end{array} \\ \text { species } A= & \begin{array}{l}\text { Total no. of Area surveyed } \times \\ \text { Area of the plot }\end{array}\end{array}$

\begin{tabular}{|c|c|}
\hline $\begin{array}{l}\text { b. Relative } \\
\text { density of }\end{array}$ & $\begin{array}{l}\text { Density of } \\
\text { species } A\end{array}$ \\
\hline . & Tot \\
\hline
\end{tabular}

b. Frequency and Relative frequency $(R F)$ :

$\begin{array}{ll}\text { a. frequency } & \begin{array}{l}\text { No. of plots in which } \\ \text { of species } A \text { occurs }\end{array} \\ A= & \begin{array}{l}\text { Total no. of plot } \\ \text { sampled }\end{array}\end{array}$

b. Relative
$\begin{aligned} & \text { Frequency of } \\ & \text { species } A=\end{aligned}$$\quad \begin{aligned} & \text { Freciency } A \\ & \begin{array}{l}\text { Total frequency value of } \\ \text { all species }\end{array}\end{aligned}$

c. Relative dominance (R. dom.) :

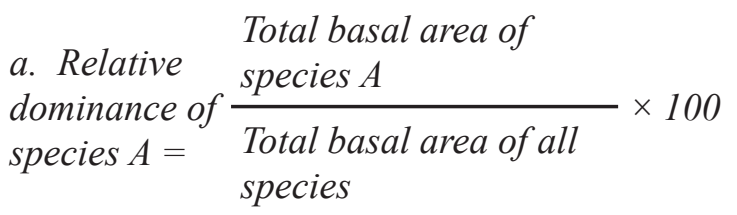

Total basal area of a particular species is a sum of basal area of all trees of that species which was calculated using the following relation:-

Basal Area $=\pi\left(d^{2} / 4\right)$

Where, $d=$ diameter at breast

\section{d) Importance value index (IVI)}

IVI was obtained by summing relative density, relative frequency, and relative dominance (Dinerstein, 1979; Poudel, K. 2009).

$I V I=$ Relative density + relative frequency + relative dominance

\section{Threats analysis}

Using SPSS and MS Excel, data were presented in pie-charts to interpret the assessed threats in Red Panda habitat.

\section{Results and discussion}

\section{Status and distribution of Red Panda}

\section{Abundance indices}

Dropping group encounter rate in the study area was found to be more at an altitudinal 
range of $3200-3400 \mathrm{~m}(1.25 / \mathrm{km})$ compared to the altitudinal range of $3000 \mathrm{~m}-3200 \mathrm{~m}(1.1 / \mathrm{km})$ whereas there was no dropping at an altitudinal range of $2800 \mathrm{~m}-3000 \mathrm{~m}$ (Table 1). The droppings were old. Up to the altitudinal range of 2800 $\mathrm{m}-3000 \mathrm{~m}$, the disturbances caused by people and livestock were more in comparison to higher altitudinal range.

Table 1: Dropping encounter rate of Red Panda in different altitudinal ranges in Simsime CF of Papung VDC

\begin{tabular}{|c|r|c|c|}
\hline $\begin{array}{c}\text { Altitudinal } \\
\text { range (m) }\end{array}$ & $\begin{array}{c}\text { Transect } \\
\text { length (m) }\end{array}$ & $\begin{array}{c}\text { Dropping } \\
\text { group } \\
\text { encountered }\end{array}$ & $\begin{array}{c}\text { Encounter } \\
\text { rate }\end{array}$ \\
\hline $2800-3000$ & 500 & 0 & 0 \\
\hline $3000-3200$ & 900 & 1 & $1.1 / \mathrm{km}$ \\
\hline $3200-3400$ & 800 & 2 & $1.25 / \mathrm{km}$ \\
\hline Total & 2200 & 3 & $3 / 2.2=1.36 / \mathrm{km}$ \\
\hline
\end{tabular}

Transect length: $2200 \mathrm{~m}$

Three Red Panda signs are shown in figure 2 in which point 1 (Height: $3125 \mathrm{~m}$, longitude: 566487 , latitude: 3048662 ) and point 2 (Height: $3127 \mathrm{~m}$, longitude: 566505 , latitude: 3048715 ) overlapped due to very small difference in altitudinal range between them and point 3 (Height: $3026 \mathrm{~m}$, longitude: 3049213, latitude: 566884) (Table 2).

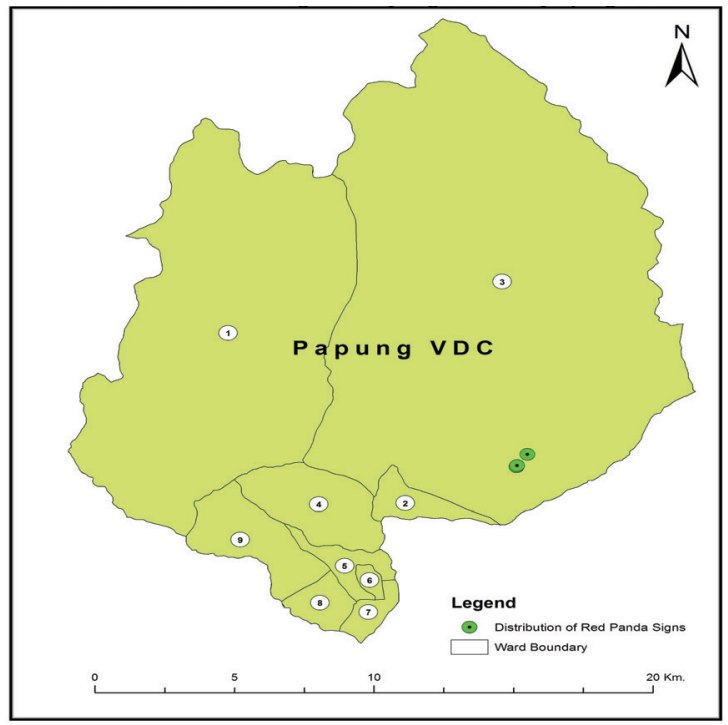

Fig. 2: Map showing the distribution of Red Panda in Simsime forest of Papung VDC
Table 2: GPS location of Red Panda dropping encounter points

\begin{tabular}{|l|l|l|l|}
\hline S. N. & Latitude (X) & Longitude (Y) & Elevation (m) \\
\hline 1 & 27.560165 & 87.67349 & 3125 \\
\hline 2 & 27.560643 & 87.673675 & 3127 \\
\hline 3 & 27.56512 & 87.677541 & 3026 \\
\hline
\end{tabular}

People's perception on population status of Red Panda in Simsime CF

About 45 per cent of the respondents were unknown about the status of Red Panda in Simsime CF, 33.33\% respondents believed that Red Panda population is declining and $22.22 \%$ respondents provided their opinion that Red Panda population is increasing (Fig. 3).

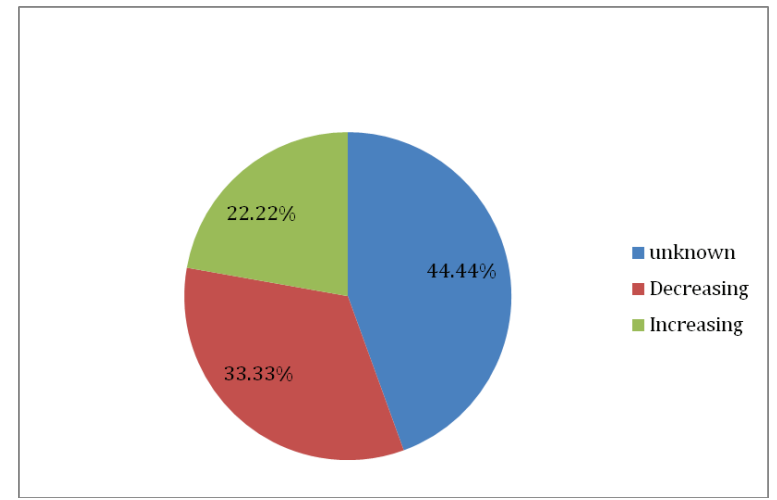

Fig. 3: People's perception on population status of Red Panda in Simsime CF

\section{Vegetation analysis}

\section{Important Value Index of Red Panda habitat}

Important Value Index (IVI) shows the dominancy of one species and the information on the occupancy of major vegetation in the area. Of the major tree species, Acer spp. had the highest IVI of 103.132 $(\mathrm{RF}=38.33$ and R. Dom. $=14.137, \mathrm{RD}=50.165)$ and Rhododendron spp. had the highest relative density $(\mathrm{RD}=80.132)$ and relative frequency (14.56) (Table 3). Pinus spp. was found to be dominant in the area due to its larger diameter than other species. Arundinaria maling was major bamboo species whereas Rubus ellipticus was major shrub species. Bamboo spp. had the higher relative frequency $(\mathrm{RF}=68.41)$ and lower relative density $(\mathrm{RD}=9.434)$ than that of $R$. ellipticus (Table 4). Fern spp. had density of 4.33 and relative frequency of 4.066 . 
Table 3: Relative density, relative frequency, relative dominance and important value index of major tree species in Simsime CF

\begin{tabular}{|c|c|c|c|c|c|}
\hline S.N. & Latin name & $\begin{array}{c}\text { Relative } \\
\text { density }\end{array}$ & $\begin{array}{c}\text { Relative } \\
\text { frequency }\end{array}$ & $\begin{array}{c}\text { Relative } \\
\text { dominance }\end{array}$ & $\begin{array}{l}\text { Important } \\
\text { value index } \\
\text { (IVI) }\end{array}$ \\
\hline 1 & Acer spp. & 50.165 & 38.33 & 14.137 & 103.132 \\
\hline 2 & Pinus spp. & 14.3 & 23.3 & 63.1 & 100.7 \\
\hline 3 & Juniperus spp. & 15.401 & 23.4 & 14.8 & 53.601 \\
\hline 4 & Rhododendron spp. & 80.132 & 14.56 & 8 & 40.567 \\
\hline & Total & 100 & 100 & 100 & 300 \\
\hline
\end{tabular}

Table 4: Density, relative density, frequency and relative frequency of major bamboo and shrub species in Simsime community forest

\begin{tabular}{|c|c|c|c|c|c|}
\hline S.N. & Latin name & D & R.D. & $\mathbf{F}$ & R.F. \\
\hline 1 & Arundinaria maling & 4.56 & 9.439 & 86.666 & 68.41 \\
\hline 2 & Rubus ellipticus & 43.75 & 90.61 & 40 & 31.58 \\
\hline & Total & 48.31 & 100 & 126.666 & 100 \\
\hline
\end{tabular}

Table 5: Density and frequency of fern species in Simsime community forest

\begin{tabular}{|l|l|l|l|}
\hline S.N. & Latin name & D & F \\
\hline 1 & Fern $s p p$. & 4.33 & 4.066 \\
\hline & Total & 4.33 & 4.066 \\
\hline
\end{tabular}

\section{Threats to Red Panda}

\section{Direct field observation}

Threat signs such as grazing, bamboo cutting, signs of other wildlife, burnt stumps, human trails and landslides were observed during field observation. Major threats to Red Panda population were grazing and bamboos cutting in which majority of the respondents agreed.

\section{People's perception}

Of the total surveyed $\mathrm{HHs}, 32 \%$ of the respondents stated that grazing was the main cause of decrease in Red Panda population in Simsime $\mathrm{CF}$, and other causes were bamboo collection ( $20 \%$ respondents), forest fire (17\% respondents), collection of forest products (13\% respondents), poaching (10\% respondents), and predation ( $8 \%$ respondents) (Fig. 4).

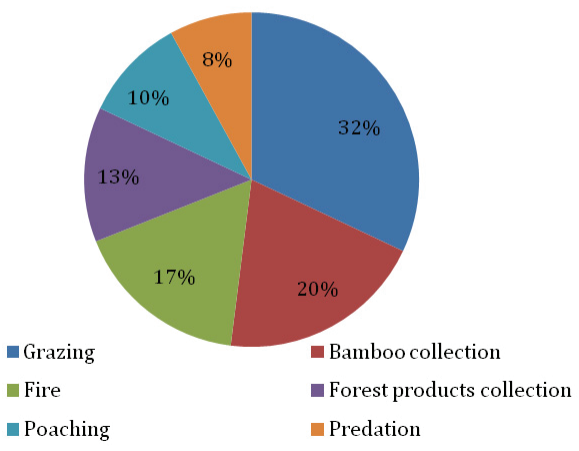

Fig. 4: People's perception on threats to Red Panda in Simsime community forest

\section{Key informants' interview}

Based on key informants' interview with project staffs and herders, livestock grazing was the major threat to Red Panda as it causes them to shift to another place due to disturbance in their 
habitat. Bamboo collection due to which their preferable food decreased was another threat to their population. Collection of non-timber forest product (NTFPs) and other forests products disturbed their habitat. Burnt stumps were observed indicating forest fire also as a threat.

\section{Conclusion}

The study area is the adjoining VDC of Kanchenjunga Conservation Area. No research of Red Panda was done earlier in this area due to which the status of Red Panda was unknown. The presence of Red Panda in Simsime community forest of Papung VDC is known from this study. Overall encounter rate of Red Panda signs in Simsime community forest was $1.36 / \mathrm{km}$ within the altitudinal range of $2800 \mathrm{~m}$ to $3400 \mathrm{~m}$ which shows the existence of Red Panda in the study area. According to direct field observation, the major threats to Red Panda population were grazing and bamboo cutting in which majority of the respondents agreed.

\section{Recommendations}

- A detailed ecological study of Red Panda is required in this region.

- In order to understand the population trend with time, regular monitoring should be done.

- Government and non-government organizations need to allocate budget to increase awareness for Red Panda conservation and uplift economic condition of local people.

- Human disturbances towards Red Panda habitat should be controlled.

- Alternate income generation programmes should be made to reduce human disturbances in the habitat.

- Regular and effective anti-poaching operation is essential.

\section{Acknowledgments}

I owe a great debt of gratitude to my Principal advisor Mr. Basudev Pokhrel and Co-advisor Mr. Gandhiv Kafle, Kanchenjunga Landscape
Concern Group (KLCG), WWF Nepal family, Mr. Badri Binod Dahal, Mr. Kamal Bhattarai, Mr. Sonam Tashi Lama, Mr. Khadananda Poudel, Mr. Dandu Shrepa, Mr. Phupu Gyabu Sherpa, Mr. Prabesh Shrestha, Ms. Shreejana Gurung and all CFUG members of Papung VDC for their direct and indirect contribution to accomplish this work successfully.

\section{References}

Bhatta, M., Shah, K. B., Devkota, B., Paudel, R. and Panthi, S. 2014. Distribution and habitat preference of Red Panda (Ailurus fulgens fulgens ) in Jumla District, Nepal. Open Journal of Ecology 4: 989-1001.

Bradford, A. 2016. Facts about Pandas, Live Science. https://www.livescience. com/57312-red-pandas.html

Chakraborty, T. 1999. Himalayan Heritage: The Endangered Red Panda. Himalayan Paryavaran 6:129-132.

Choudhary, A. 2001. An overview of the status and conservation of the Red Panda, Ailurus fulgens in India with reference to its global status. Oryx 35(3):250-259.

Dinerstein, F. 1979, An ecological survey of the Royal Karnali Bardia Willife Reserve Nepal Part-I; Vegitation modifying factors and successional relationship Bilogical Conservation 15 : 127-150.

DNPWC. 2010. Red Panda (Ailurus fulgens) Conservation Action Plan for Langtang National Park, Nepal. Department of National Parks and Wildlife Conservation (DNPWC), Babarmahal, Kathmandu, Nepal.

DNPWC.1995. Biodiversity Assessment of Forest Ecosystems of the Eastern Midhills of Nepal. Biodiversity Profiles Project. Publication No 9. Department of National Parks and Wildlife Conservation (DNPWC), Kathmandu, Nepal.

Glatston, A. R. 1994. Status Survey and Conservation Action Plan for Procyonids and Ailurids: The Red Panda, Olingos, Coatis, Raccoons, and their Relatives. 
IUCN, Gland, Switzerland.

Gysel, L. J. and Lyon, L. J. 1980. Habitat analysis and evaluation. In Wildlife Management Techniques Manual (ed.) Schemnitz, S. D., The Wildlife Society, Washington DC, USA., 305-327.

Himalayan News Service. 2019. Five-year Red Panda conservation action plan developed. Kathmandu, Nepal.

Johnson, K. G., Shaller, G. B. and Jinchu, H. 1988. Comparative behavior of Red and Giant Pandas in the Wolong Reserve, China. Journal of Mammology 69 (3):552-564.

Karki, J. B. 1999. A study on Red Panda Habitat at Cholangpati area of Langtang National Park. Department of National Parks and Wildlife Conservation, Kathmandu, Nepal.

Ling, $\mathrm{Xu}$ and Jing, Guan. 2018. Red Panda Market Research Findings in China. Traffic Briefing Paper.

Mahato, N. K. 2003. Status of Red Panda Ailurus fulgens (cuvier, 1825) in the Kanchanjungha Conservation Area. B.Sc. project paper submitted to Institute of Forestry, Tribhuvan University, Pokhara.

Morris, D. 1965. The Mammals: A Guide to the Living Species. Harper and Row, New York and Evanston.

Panthi, S., Aryal, A., Lord, J., Adhikari, B. and Raubenheimer, D. 2012. Summer diet and distribution of Red Panda (Ailurus fulgens fulgens) in Dhopatan Hunting Reserve, Nepal. Zool Stud 51:701-709.

Poudel, K. 2009. Status, Distribution and Threats of Red Panda in Manang district, Nepal. Lambert academic publishing.

Pradhan, S., G. K. Saha and J. A. Khan. 2001a. Ecology of the red panda Ailurus fulgens in the Singhalila National Park, Darjeeling, India. Biological Conservation 98: 11-18.

Roberts, M. S. and Gittleman, J. L. 1984. Ailurus fulgens. Mammalian species. American Society of Mammologist 222: 1-8.
Shrestha, K. K. and Ghimire, S. K. 1996, Plant Diversity Inventory and Vegation Analysis in the Shey Phoksundo National Park, (Phoksundo and Jagdulla Valley) a report summitted to WWF Nepal program, Kathmandu Nepal

Shrestha, M. 1988. Vegetation Study of Red Panda in Langtang National Park, Central Nepal. Central Department of Zoology. Kirtipur Campus, Tribhuvan University.

Thapa, A., Wu, R., Hu, Y., Nie, Y. Singh, PB., Khatiwada, JR., Yan, L., Gu, K. and Wei, F. 2018. Predicting the potential distribution of the endangered Red Panda across its entire range using MaxEnt modeling. Wiley Online Library, Ecology and Evolution/Volume 8, Issue 21 Publisher, place, country?

Vaughan, T. A. 1972. Mammology. W. B. Saunders Company; Philadelphia, London and Toronto.

Wei, F. W., Feng Z. J., Wang Z. W. and J. W. Hu. 1999. Current distribution, status, and conservation of wild red pandas (Ailurusfulgens) in China. Biological Conservation 89 (3): 285-291

Yonzon, P. 2000. Opportunities in Ecoregion Based Conservation in Kanchenjunga Region, Eastern Nepal. In Kanchenjunga Mountain Complex: Biodiversity Assessment \& Conservation Planning, WWF Nepal Program, Kathmandu, 1-29.

Yonzon, P. B. 1989. Ecology and Conservation of the Red Panda in the Nepal Himalayas. Ph. D. Dissertaion, submitted to University of Maine, Orono, Maine, USA.

Yonzon, P., Yonzon, P., Chaudhary, C. and Vaidya, B. 1997. Status of the Red Panda in the Himalaya. A Resources Nepal. Kathmandu and Metropolitan Toronto Zoo Project, Toronto Canada. pp21.

Yonzon, P. B. and Hunter, M. L. 1989. Ecological Study of the Red Panda in the Nepal Himalayas. SPB Academic Publishing. The Hague, the Netherlands. 